IRSTI 06.52.45

UDC 336.76

https://doi.org/10.46914/1562-2959-2021-1-4-70-76

\author{
S.N. ABIEVA, ${ }^{1}$ \\ s.e.s. \\ e-mail: abievas@mail.ru \\ G.G. ILYASOVA, $* 1$ \\ $\mathrm{PhD}$ student. \\ *e-mail: g-iliyasova@mail.ru \\ ${ }^{1}$ Kazakh national University named \\ after al-Farabi, Kazakhstan, Almaty
}

\title{
MONETARY AND EXCHANGE POLICY OF KAZAKHSTAN: CURRENT PROBLEMS AND WAYS OF IMPROVEMENT
}

\begin{abstract}
The National Bank of Kazakhstan continues to pursue monetary policy in accordance with the principles of inflation targeting. As part of the medium-term strategy, the National Bank has reduced the target inflation corridor by one percentage point in 2020. Due to the global crisis of recent years, the National Bank has set a task to keep the inflation rate in the $4-6 \%$ corridor to stabilize the economy. The inflation rate at the end of 2020 was $7.5 \%$. The National Bank has set a task to reduce this indicator to the level of the target corridor of 4-6\% in 2021. Also, in conducting monetary policy, the National Bank has made decisions that have an anti-inflationary effect for the medium term, that is, the target level will decrease by $4 \%$ in 2021 and beyond. The preservation of monetary conditions by the regulator at a neutral level was characterized by a decrease in short-term rates after slow inflation. In 2019, against the background of a further decrease in inflation, it was decided to raise the base rate. At the same time, market participants may regard monetary conditions as the beginning of tightening. In Kazakhstan, the financial regulator sets the rate depending on the size of real and expected inflation in the country, external factors that determine the state of the balance of payments, as well as taking into account the need to maintain economic development. The article discusses the methods of conducting the monetary and monetary policy of Kazakhstan, as well as issues and ways to improve it.
\end{abstract}

Key words: monetary and exchange rate policy, tenge, percentage point, inflation, devaluation, budget, base rate.

\section{Introduction}

In Kazakhstan, the situation on the foreign exchange market remains volatile. From the second quarter to the 3 rd quarter of this year, the tenge exchange rate strengthened by $1.2 \%$. The exchange rate depends on the balance of payments of the country that is under the influence of the balance of inflows and outflows of foreign currency to the country's market. It allows to minimize external shocks and to support indicators of competitiveness of our economy [1].

The policy of floating exchange rate of tenge allows to keep gold and currency reserves. The gold and foreign exchange reserves of the National Bank as of July 1, 2021 amounted to \$ 34.9 billion, and the assets of the National Fund $-\$ 57.3$ billion. The total volume of international reserves is $\$$ 92.5 billion (in June, the international reserves of the National Bank of the Republic of Kazakhstan decreased by $3.9 \%$ ). According to analysts the increase in spending due to the allocation of additional funds on social support will not make considerable impact on acceleration of inflation processes. The risks of increasing inflation in 2019 are based on the increase in excise taxes on fuel, the persistence of high inflation expectations, and a slight increase in wage, primarily due to an increase in the minimum wage.

In addition, the weakening of the tenge in 2020 has not yet fully transferred to prices, which was reflected in its impact in the first half of 2021. Despite the fact that the state budget expenditures are reduced, transfers of the National Fund are replaced by funds from extrabudgetary funds - the National Bank, the Common National Pension Fund including the expenses of national holdings. As a result, the inflation rate at the end of 2019 was $5.4 \%$, and at the end of 2020 , the inflation rate was $7.5 \%$. 


\section{Materials and methods}

The planned hike in government spending creates great risks of a sharp rise of inflation. The economy of Kazakhstan very strongly depends on the export of natural resources therefore one of the key objectives of economic policy is to reduce the dependence of the state budget on the situation in the world commodity markets to maintain long-term fiscal stability. According to the International Monetary Fund and the World Bank it is very important for Kazakhstan to move to a stable level of non-oil deficit of the country's consolidated budget in the range of 5-6\% of GDP. For saving the financial resources of the National Fund through the forming of savings for the future generations and reducing the dependence of the state budget of the situation in the world commodity markets at the end of 2016 the Concept of the formation and the currency use of the National Fund (hereinafter the Concept) was approved by the President's decree.

In our opinion, this document contains very important budgetary rules which allow to support the long-term fiscal stability of Kazakhstan, which strengthens the investment attractiveness of the country and increases the trust to economic policy of the authorities. The concrete plans were set up in the Concept for the years from 2017 to reduce the level of non- oil deficit to 7\% of GDP in 2021 and to $6 \%$ of GDP in 2025. But these plans were not implemented during 2017-2019. Such significant recessions from the previously approved policy to reduce the non-oil deficit demonstrate the low discipline in the implementation of the plans and the inconsistency in economic policy [2].

\section{Main provisions}

According to the analysts at the last meeting of the ruling party of Nur Otan at the end of February the new initiatives of the welfare gain and the living standards, the housing access of citizens with low - income, the improvement of education and health care as well as regional development were announced.To implement the announced measures it will be required 2,350 trillion tenge, which will be shared for three years until 2022.

1.35 trillion tenge and 1 trillion tenge were allocated from the National Fund due to the economic return of previously overdue expenses from additional state budget revenues and improvement of customs administration. Th additional use of the National Fund in 2019 will lead to the fact that with good oil prices the Fund will stop growing and even slightly decrease.

The concern is that the planned sharp increase of national spending may coincide with changes in the monetary policy of the National Bank in connection with the change of its leadership. There are high risks of sharp strengthening of inflation in response to stimulating nature of both fiscal and monetary policies.

The decline in inflation rates in January and February of this year has artificial character due to administrative decrease in utility tariffs. Without reduction of tariffs the monthly inflation would be $0.8 \%$ in January and $0.9 \%$ in February, 2020 that is higher than inflation in similar months of the last year (in January of $2019-0.6 \%$ of $\mathrm{m} / \mathrm{m}$, in February - 0.7\%). The expenses on the social sphere are planned for this year in the volume of 4.7 trillion tenges that makes over $40 \%$ of the total amount of expenses of the budget [3].

\section{Results}

The monetary policy regulator will continue to have a limited impact on inflation processes in the country as they are not monetary in nature and the effect of the transmission on price inflation will be limited within the interest rate channel. The impact of the regulator on inflation expectations is also limited. In 2018 the exchange rate of the national currency to the US dollar depreciated from 430 tenge to 424 tenge while the exchange rate of tenge to the Russian ruble remained at the level of 5,5-5,6 [4].

The sentiment of Kazakhstan's foreign exchange market participants strongly depends on external macroeconomic changes in particular on the Russian ruble and oil prices rate. For the dynamics of tenge the world oil prices act as the major fundamental factors (since oil is the main export goods with a share of about $60 \%$ in structure of export) and the rate of the Russian ruble (due to the large volume of trade with Russia). At the same time, oil prices are the determining factor in the long-term forecast 
and the increase in the volatility of the Russian ruble serves as a trigger for changes in the exchange rate of tenge in the short term. In Kazakhstan the low rate of inflation and the reduction of external risks including the risks of the oil price downturn provides a short-term forecast of stabilization of the exchange rate of tenge. Rather high level of hydrocarbon prices, stabilization of GDP growth, the growing external surplus of Kazakhstan, the inflow of foreign direct investment have a positive impact on the exchange rate of tenge in 2019. In 2020, the repayment of external debt was slightly higher than in 2018, which also has a negative impact on the national currency of Kazakhstan.

We believe that the National Bank of Kazakhstan in 2021 will follow its silent policy of "weak" tenge to the Russian currency which in turn will react very sensitively to the further expansion of antiRussian sanctions as well as the targeted weakening of the Russian ruble from the monetary authorities of the Russian Federation within the budgetary rule. We believe that with the average annual cost of Brent crude oil at $\$ 68$ per barrel and the average annual exchange rate of the Russian ruble to the US dollar at 67 rubles the national currency will be at the level of 375 tenge per US dollar on average for the year. As well as last year in 2021 quotations on hydrocarbons will determine the long-term trend by pair and the changes in USDRUB pair will determine the current values of the national currency.

Kazakhstan has a lot of supporters of the policy of maintaining a weak tenge against the ruble. First of all, it is favorable to the government and the raw exporters as the combination of high world oil prices and weak tenge gives the strong support to their income. The National Chamber of Entrepreneurs "Atameken" also looks positively at the weak tenge to ruble in order to support the growth of competitiveness of Kazakh producers in their fight against Russian import. In favour of the artificial lowering of the national currency the competition disappears - this is a kind of a peculiar price dumping. In the case of a weak tenge paired with the ruble artificially inflated the prices of goods and services imported from Russia.

This gives the competitive advantage to the domestic companies which make similar products. Besides the price protection the artificial depreciation of the national currency it is regarded the lower salaries in the country in terms of foreign currency which also gives a certain competitive advantage in comparison with other countries. The artificial understatement creates the competitive advantages due to the growth of inflation and decrease in welfare of the population. Especially strongly it affects the import-dependent countries such as Kazakhstan. In other words there is an artificial redistribution of income in the economy. Exporters (primarily of raw materials) as well as companies engaged in the import substitution are actually "subsidized" by the population expense which will pay at higher prices [5].

\section{Discussion}

The other negative side is that the price protection of exporters and producers due to the undervalued rate of national currency does not lead to the growth of quality and production efficiency. There are numerous international researches confirming it. The artificial protection against the competition from the state does not encourage such enterprises to develop their competitiveness independently.

The weakening of the exchange rate increases the prices and reduces the demand for import investment goods primarily equipment and components. Taking into account the fact that Kazakhstan practically does not produce the complex equipment and the installation of the equipment is carried out from the imported components the increase in prices for investment imports will primarily have a negative impact on the investment plans of capital-intensive and high-tech productions.

There are numerous international researches that suggest that competitiveness of a weak national currency is relevant only for the simple and labor-intensive companies and it limits the growth of capital-intensive and high-tech companies. China is often cited as a positive example of the understated national currency. There are suggestions from the recent researches that in this country the weak yuan contributed to the growth of simple and labor-intensive industries in the period of initial industrialization and urbanization. And after reaching a certain level of industrialization the depreciation of the yuan has become an obstacle to economic growth and diversification [6].

Another negative side of the weak tenge is the growth of devaluation expectations. As a result of the policy of the National Bank this figure in January 2019 was about $63.3 \%$ and in February it grew to $68 \%$. Such large negative trends in the devaluation expectations of the population mean one thing - a 
decrease in trust to the monetary and exchange rate policy of the National Bank which ultimately will have a bad impact on the entire economy.

First of all, the National Bank should move away from the policy of weak tenge to any currency. It has to accustom the market that the tenge primarily depends on oil and quite a bit on ruble. For example, when the ruble sharply weakens due to sanctions in Russia the National Bank should not allow tenge to weaken following the ruble because it does not correspond to the economic realities in Kazakhstan. As market prices of oil are volatile the rate of tenge to dollar will also be volatile until we are able to diversify our economy. In such situation it is very important to develop the market of instruments of hedging of currency risk (futures, forwards, swaps, options, etc.). Certain steps in this direction were already taken but we are at very early stage of development of this market.

The expansion of extractive capacities on the large scale oil fields of Tengiz and Kashagan will contribute to the economic growth both at the investment stage and subsequently through production growth. The average cost of a barrel of Brent crude oil in 2018 was $\$ 70$ per barrel increasing from $\$ 54$ for barrel in 2017 though in December 2018 it reached $\$ 50$ for barrel. Forecast prices for Brent crude oil in 2021 based on the expectations of the international financial organizations are expected to be at the level of 71 US dollars for barrel.

Monetary policy in Kazakhstan is important for the development of the economy, but it cannot serve as a source of sustainable growth of economic potential. Factors that reflect the potential for economic growth in the long term are labor productivity and capital changes, as well as the speed of introduction of new technologies. The National Bank cannot influence the productivity of production factors and the introduction of technologies by means of monetary policy. In order to maintain price stability, the Central Bank influences the dynamics of domestic demand and, as a result, the state of the use of production factors. Thus, monetary policy is not the economic potential itself, and, therefore, affects the deviation of economic growth rates from the potential.

In our opinion, this situation develops as a result of the preservation of structural problems in the economy, the dominance of the raw sector with the weakness of the medium-sized businesssegment, the collected internal problems of the banking system, the significant predominance of the state in the economy. Despite the good growth of economy there is a rather weak growth of deposits in the banking sector. The main driver of the growth of deposits in 2020 was the growth of deposits of the population, while the dynamics of growth of deposits of the corporate sector shows stagnation. In our opinion, the lack of growth of corporate deposits is due to the significant withdrawal and placement of foreign currency earnings of exporters on the foreign currency accounts in foreign banks.

It should be noted that the significant mobility of deposits in 2020 grow up, primarily corporate between banks caused by the withdrawal from the market of a number of banks, the emergence of problems in Tsesnabank, the movement of deposits to large banks and banks with foreign participation.

Concerning exchange securities market it is possible to note that the National bank together with the Kazakhstan Stock Exchange (KASE) also realized a number of initiatives such as the transition of calculations of the official rate of tenge to US dollar since October 1, 2018 to the $\mathrm{T}+1$ scheme, the introduction of the Institute of the central counterparty on the currency market of KASE from October 1, 2018. The debut issue of eurobonds denominated in tenge international financial institution on the platform of the Kazakhstan Stock Exchange with carrying out payments in tenge took place. This placement was the first issue of securities of the Issuer with AAA credit rating on the KASE platform.

In 2019, the National Bank retained the current set of instruments as permanent access operations, which includes direct and reverse REPO operations, currency swap on the Kazakhstan Stock Exchange, deposits of second-tier banks with the National Bank. As operations of the open market it is planned to use the auction of notes of National Bank, an auction for purchase of securities with the return sale (a credit auction). In addition to the current operations of the open market it is planned to introduce a deposit auction as an alternative to short-term notes with a circulation period of 7 days [7].

The credit portfolio of the banking system shows no significant growth. This result was influenced by the withdrawal from the system of a number of banks and the redemption of problem loans "Tsesnabank" in the amount of 450 bn tenge. Also, the overall dynamics of the loan portfolio includes the implementation of significant write-offs of previously hidden problem loans and their replacement with new loans, mainly in the corporate lending segment. At the same time, the reduction in the corporate loan portfolio was replaced by a significant increase in retail lending, which showed an 
increase of more than $15 \%$ since the beginning of the year. Such a high growth dynamics of the retail sector both in lending and in attracting deposits reflects a significant increase in the focus of most banks in the sector on servicing the population.

From 2019 to the current 2021, the trend of further deterioration of the financial situation of second-tier banks continues. This process is happening, firstly, because of the financial downturn caused by the global pandemic, and because of the inefficient business models of these banks and increased competition for high-quality borrowers and depositors with large banks.

The transition to more active lending and the growth of the share of the banking sector in the economy are possible only after the resolution of a number of structural problems in the economy and the construction of a more effective market mechanism for the provision of financial services. Thus, the total number of applications for mortgage loans under the 7-20-25 program in 2019 amounted to 11,021 in the amount of 125.4 billion tenge. 75.2 billion 6450 applications were approved for the amount of 60.4 billion tenge. 5,085 tenge-denominated loans were issued. And in $2020-10,207$ (120.8 billion tenge). Retail crediting, as well as in general emphasis on service of the population (card products, online banking) will continue to act as the main driver of development of a banking system of Kazakhstan. The growth of large business deposits will be positively influenced by the restoration of confidence in the banking system and fairly good economic growth expected in 2021-2022. As a result of the recovery of income growth, deposits will continue to grow, which will be slightly higher than the results of 2019. The growth of retail lending will continue to show high rates, continuing the current dynamics with a gradual slowdown. The growth of corporate lending will remain rather restrained and will be significantly lower than the nominal GDP growth. The increase in corporate lending will mainly depend on the resolution of structural problems and the growth of the share of small and medium-sized businesses in the economy [8].

In order to avoid a repetition of the situation with the policy of high-risk banks, as well as to strengthen the mandate of the National Bank for regulation and supervision, a risk-oriented approach has been introduced into the supervisory process since January 1, 2019. In addition, we are moving to the regime of resolution and settlement of problem banks (Recovery and Resolution tools), which provides for mechanisms of forced restructuring of the bank's obligations. These innovations are implemented in Kazakhstan's practice, taking into account the international experience implemented in the European Union, the United States, as well as in the Euroasian Economic Union, in particular, following the example of Russia and Belarus. The reasoned judgment will be used in the part of coordination of management and shareholders, assessment of adequacy of the created provisions, determination of the persons connected with Bank by the special relations, and also an assessment of systems of risk management and internal control. The purpose of the introduction of the Institute of judgment is to prevent the risks of financial institutions at an early stage in order to protect the rights and interests of investors, customers and other interested counterparties.

The model of risk-based supervision allows to identify risks and shortcomings in the activities of banks in advance in order to take effective measures to eliminate and subsequently prevent such risks. The National Bank took the methodology of SREP (Supervisory Review and Evaluation Process) which is recognized as the European Central Bank and is applied in the countries of the European Union as a basis and also corresponds to the last recommendations of the Basel Committee on banking supervision.

\section{Conclusion}

The coordination of monetary, budgetary and monetary policy is a necessary condition for sustainable development of Kazakhstan's economy. Taking into account the economic characteristics of Kazakhstan we can reduce the real interest rate thereby improving the effectiveness of the above mentioned policies, subject to several mandatory conditions:

- The efficiency and independence of monetary policy of the National Bank is necessary.

- The transparency, predictability and stability of fiscal policy is necessary.

- There is a need for clear coordination and close coordination of monetary and fiscal policies.

- The rate of tenge should not be artificially weakened. 


\title{
REFERENCES
}

1 Jordan A. Monetary policy in Asian governments. Seoul: Asia Centre of analyses, 2018.

2 Internet resources of the official website of the National Bank of the Republic of Kazakhstan www. nationalbank.kz

3 Sembieva L.M. Monetary policy in ensuring the sustainable development of the economy of Kazakhstan: theory, methodology, implementation mechanism: Monograph Almaty: Color, 2018. 416 p.

4 Volchanin A.S. The problem of monetary policy in developing countries // Report of the International Commission for Asian Countries. Paris: UNESCO, 2019. 40 p.

5 Tolkachev A.N. On targeted inflation // Money and credit, 2018, no. 9, pp. 14-26.

6 Levakov I.S. Monetary policy of Russia in the conditions of sanctions and after the crisis // Synergy of Sciences, 2018, no. 20, pp. 12-19.

7 Chelekbai A.D. New challenges to monetary policy. Money and Credit - Money and Credit, 2018, no. 9, pp. 6-8

8 Oil prices are falling, what is the political burden of various oil-producing countries? URL: http://twep. $\mathrm{kz} / \mathrm{ru} / \mathrm{kommentariieksperta/2020-4-25}$

9 Oil prices are falling, what is the policy of various oil-producing countries? // Drobyshevsky S., Kozlovskaya A., Trunin P. The choice of monetary policy in the countries-oil exporter. M.: IEPP, 2018. 136 p.

10 The credit portfolio of the banking system. Guidelines for Educators in the Asia Region. Bangkok: UNESCO, 2018.

\section{С.Н. АБИЕВА, ${ }^{1}$}

Э.Ғ.К.

e-mail: abievas@mail.ru

Г.Г. ИЛЬЯСОВА, оқытушы.

*e-mail: g-iliyasova@mail.ru 'әл-Фараби атындағы Қазақ ұлттық университеті, Қазақстан, Алматы қ.

\section{ҚАЗАҚСТАННЫҢ АҚША-НЕСИЕ ЖӘНЕ ВАЛЮТАЛЫҚ САЯСАТЫ: ҚАЗІРГІ ЗАМАНҒЫ МӘСЕЛЕЛЕР ЖӘНЕ ОНЫН ЖЕТІЛДІРУ ЖОЛДАРЫ}

\begin{abstract}
Андатпа
Қазақстан Ұлттық банкі инфляциялық таргеттеу қағидаттарына сәйкес ақша-кредит саясатын жүргізуді жалғастыруда. Орта мерзімді стратегия шеңберінде Ұлттық Банк 2020 ж. инфляцияның нысаналы дәлізін бір пайыздық тармаққа төмендетті. Соңғы жылдардағы әлемдік дағдарысқа байланысты Ұлттық банк экономиканы тұрақтандыру үшін инфляция деңгейін 4-6\% дәлізінде сақтау міндетін қойды. 2020 ж. соңында инфляция деңгейі 7,5\% құрады. Ұлттық банк бұл көрсеткішті 2021 ж. 4-6\% нысаналы дәліз деңгейіне дейін төмендету міндетін қойды. Сондай-ақ, ақша-несие саясатын жүргізуде Ұлттық банк орта мерзімді кезеңге инфляцияға қарсы әсер ететін шешімдер қабылдады, яғни нысаналы деңгей 2021 ж. 4\%-ға және одан әрі төмендей береді. Реттеушінің ақша-кредит шарттарын бейтарап деңгейде сақтауы баяу инфляциядан кейін қысқа мерзімді мөлшерлемелердің төмендеуімен сипатталды. 2019 ж. инфляцияның одан әрі төмендеуі аясында базалық мөлшерлемені көтеру туралы шешім қабылдады. Осы ретте, нарық қатысушылары ақша-несие шарттарын қатаңдатудың бастауы ретінде бағалауы мүмкін. Қазақстанда қаржылық реттеуші елдегі нақты және күтілетін инфляцияның мөлшеріне, төлем балансының жағдайын анықтайтын сыртқы факторларға, сондай-ақ экономикалық дамуды қолдау қажеттілігін ескере отырып мөлшерлеме белгілейді. Мақалада Қазақстанның ақша-несие және валюта саясатын жүргізу әдістері, сондай-ақ оны жетілдіру мәселелері мен жолдары қарастырылады.
\end{abstract}

Тірек сөздер: ақша-несие және валюталық саясат, теңге, пайыздық тармақ, инфляция, девальвация, бюджет, базалық мөлшерлеме. 
С.Н. АБИЕВА, ${ }^{1}$

К.Э.Н.

e-mail: abievas@mail.ru

Г.Г. ИЛЬЯСОВА,

преподаватель.

*e-mail: g-iliyasova@mail.ru

${ }^{1}$ Казахский национальный университет

им. аль-Фараби, Казахстан, г. Алматы

\title{
ДЕНЕЖНО-КРЕДИТНАЯ И ВАЛЮТНАЯ ПОЛИТИКА КАЗАХСТАНА: СОВРЕМЕННЫЕ ПРОБЛЕМЫ И ПУТИ СОВЕРШЕНСТВОВАНИЯ
}

\begin{abstract}
Аннотация
Национальный банк Казахстана продолжает проводить денежно-кредитную политику в соответствии с принципами инфляционного таргетирования. В рамках среднесрочной стратегии Нацбанк снизил целевой коридор инфляции на один процентный пункт в 2020 г. В связи с мировым кризисом последних лет Нацбанк поставил задачу сохранить уровень инфляции в коридоре 4-6\% для стабилизации экономики. Уровень инфляции на конец 2020 г. составил 7,5\%. Нацбанк поставил задачу снизить этот показатель до уровня целевого коридора 4-6\% в 2021 г. Также в проведении денежно-кредитной политики Национальным банком приняты решения, оказывающие антиинфляционный эффект на среднесрочный период, то есть целевой уровень снизится на 4\% в 2021 г. и далее. Сохранение денежно-кредитных условий регулятором на нейтральном уровне характеризовалось снижением краткосрочных ставок после медленной инфляции. В 2019 г. на фоне дальнейшего снижения инфляции было принято решение о повышении базовой ставки. При этом участники рынка могут расценивать кредитно-денежные условия как начало ужесточения. В Казахстане финансовый регулятор устанавливает размер ставки в зависимости от размера реальной и ожидаемой инфляции в стране, внешних факторов, определяющих состояние платежного баланса, а также с учетом необходимости поддержания экономического развития. В статье рассматриваются методы проведения денежно-кредитной и валютной политики Казахстана, а также вопросы и пути ее совершенствования.
\end{abstract}

Ключевые слова: денежно-кредитная и валютная политика, тенге, процентный пункт, инфляция, девальвация, бюджет, базовая ставка. 